\title{
The Infection Rate of the Coronavirus Disease 2019 (COVID-19) in Wuhan, China
}

Hui-Qi Qu ${ }^{1}$, Zhangkai J. Cheng ${ }^{1,2}$, Zhifeng Duan ${ }^{1,2}$, Lifeng Tian ${ }^{1}$, Hakon Hakonarson ${ }^{1,3^{*}}$

${ }^{1}$ Center for Applied Genomics, The Children's Hospital of Philadelphia, Philadelphia, Pennsylvania, USA

${ }^{2}$ Institute of Allergy and Immunology, School of Medicine, Shenzhen University, China

${ }^{3}$ Divisions of Human Genetics and Pulmonary Medicine, Department of Pediatrics, The Perelman School of Medicine,, University of Pennsylvania, Philadelphia, Pennsylvania, USA

Word count: 512

* Corresponding author:

Dr. Hakon Hakonarson

Center for Applied Genomics, The Children's Hospital of Philadelphia, Philadelphia,

Pennsylvania, United States of America, Department of Pediatrics, University of Pennsylvania, Philadelphia, Pennsylvania, United States of America

Email: $\underline{\text { Hakonarson@chop.edu }}$ 
medRxiv preprint doi: https://doi.org/10.1101/2020.05.02.20088724; this version posted May 8, 2020. The copyright holder for this preprint (which was not certified by peer review) is the author/funder, who has granted medRxiv a license to display the preprint in perpetuity.

All rights reserved. No reuse allowed without permission.

\section{Summary Box}

\section{What is already known about this subject?}

The Wuhan city in China had a much higher mortality rate (Feb 10 ${ }^{\text {th }}$ statistics: 748 death/18,454 diagnosis $=4.05 \%$; Apr $24^{\text {th }}$ statistics: 3,869 death/50,333 diagnosis=7.69\%) than the rest of China.

\section{What are the new findings?}

Based on our analysis, the number of infected people in Wuhan is estimated to be 143,000 $(88,000$ to 242,000$)$ in late January and early February, significantly higher than the published number of diagnosed cases.

\section{What are the recommendations for policy and practice?}

Increased awareness of the original infection rates in Wuhan, China is critically important for proper public health measures at all levels, as well as to eliminate panic caused by overestimated mortality rate that may bias health policy actions by the authorities 
medRxiv preprint doi: https://doi.org/10.1101/2020.05.02.20088724; this version posted May 8, 2020. The copyright holder for this preprint (which was not certified by peer review) is the author/funder, who has granted medRxiv a license to display the preprint in perpetuity. All rights reserved. No reuse allowed without permission.

The pandemic of the Coronavirus Disease 2019 (COVID-19) started in Wuhan, China in December 2019. Wuhan is a megacity with a population of about 11 millions. To prevent the spread of this alarming infectious disease, the whole city was locked down by the government since Jan $23^{\text {rd }}, 2020$. However, despite the efforts, COVID-19 has spread to many countries across the world, and is causing an unprecedented pandemic as well as serious public health concern considering its high mortality rate. According to the large-sample analysis by $\mathrm{Wu}$ and McGoogan(1,2), the case-fatality rate (CFR) was $2.3 \%$ in China, i.e. 1023 of $44 \square 672$ confirmed cases by February 11, 2020 with a significant proportion of the cases from Wuhan. The large number of infected people in the city of Wuhan had put a tight strain on essential medical resources. The city had a much higher mortality rate (Feb $10^{\text {th }}$ statistics: 748 death/18,454 diagnosis $=4.05 \%$; Apr $24^{\text {th }}$ statistics: 3,869 death $/ 50,333$ diagnosis=7.69\%) than the rest of China. Therefore, the overall CFR of $2.3 \%$ in China was likely overestimated, due to strained medical resources and a large number of undiagnosed patients. According to the most recent study, $78 \%$ infections were asymptomatic(3). Therefore, a large number of asymptomatic infections in Wuhan might have never been diagnosed, which contributed to the overestimated CFR. To get an accurate estimation of infections is therefore important to assess the CFR in Wuhan precisely.

Using Markov Chain Monte Carlo methods, Wu et al. estimated that 75,815 individuals (95\% CI: 37,304, 130,330) had been infected in Wuhan as of Jan 25, 2020(4). After this study, a number of foreign governments evacuated their citizens and performed thorough etiological tests for these people. The evacuation of people can serve as a "random" sample to estimate the infection rate in Wuhan. Using these publicly available data (Table 1), we performed a combined analysis of the infection rates of these population samples, instead of a simple pooled calculation, considering potential different life styles and pathogen exposures across different populations. The combined analysis was done using the Comprehensive Meta-Analysis Software (CMA).

Shown in our analysis, there is no significant heterogeneity across different population samples (heterogeneity test $\mathrm{P}=0.491)$. The combined infection rate $(95 \% \mathrm{CI})=0.013(0.008$, 0.022) (Fig.1). Based on these results, the number of infected people in Wuhan is estimated to be 143,000 (88,000 to 242,000), or significantly higher than the estimate by Wu et al(4). By our estimation, it is safe to say that a large number of infections in Wuhan, China have not been diagnosed (the number of undiagnosed in late January and early February is much more than the final diagnosed number 50,333 to date), causing the CFR being over-estimated. In addition, our estimation suggests that the lower CFR $(0.51 \%)$ estimated by the Centre for Evidence-Based Medicine(2) doesn't mean viral variants and loss of virulence. Taken together, increased awareness of the original infection rates in Wuhan, China is critically important for proper public health measures at all levels, as well as to eliminate panic caused by overestimated mortality rate that may bias health policy actions by the authorities. 
medRxiv preprint doi: https://doi.org/10.1101/2020.05.02.20088724; this version posted May 8, 2020. The copyright holder for this preprint (which was not certified by peer review) is the author/funder, who has granted medRxiv a license to display the preprint in perpetuity.

All rights reserved. No reuse allowed without permission.

Table 1 Number of infected people from different countries

\begin{tabular}{|c|c|c|c|c|}
\hline Country & $\begin{array}{l}\text { Evacuatio } \\
\text { n date }\end{array}$ & $\begin{array}{l}\text { Confirmed } \\
\text { cases }\end{array}$ & $\begin{array}{l}\text { Evacuated } \\
\text { number }\end{array}$ & Data sources \\
\hline Japan & NA & 9 & 566 & $\begin{array}{c}\text { https://www.mhlw.go.jp/stf/newpage_0939 } \\
\text { 6.html }\end{array}$ \\
\hline Korea & 31-Jan & 1 & 368 & $\begin{array}{l}\text { http://world.kbs.co.kr/service/news_view.h } \\
\text { tm?lang=c\&Seq_Code=66621 } \\
\text { https://www.mohw.go.kr/eng/nw/nw0101v } \\
\text { w.jsp?PAR_MENU_ID=1007\&MENU_ID } \\
=100701 \& \text { page=1\&CONT_SEQ=352718 } \\
\text { http://www.mohw.go.kr/react/al/sal0301v } \\
\text { w.jsp?PAR_MENU_ID=04\&MENU_ID= } \\
\text { 0403\&page=3\&CONT_SEQ=352645 }\end{array}$ \\
\hline Germany & $1-\mathrm{Feb}$ & 2 & 124 & $\begin{array}{l}\text { https://www.dw.com/en/coronavirus- } \\
\text { german-evacuation-flight-from-china- } \\
\text { carried-two-infected-people/a-52229955 }\end{array}$ \\
\hline $\begin{array}{c}\text { Singapor } \\
\mathrm{e}\end{array}$ & 30-Jan & 1 & 92 & $\begin{array}{c}\text { https://www.nst.com.my/world/world/2020 } \\
\text { /01/561086/coronavirus-countries- } \\
\text { evacuate-citizens-china } \\
\text { https://www.straitstimes.com/singapore/so } \\
\text { me-singaporeans-with-symptoms-of-virus- } \\
\text { staying-behind-in-wuhan-even-as-92-are- } \\
\text { evacuated } \\
\text { https://www.straitstimes.com/singapore/co } \\
\text { ronavirus-2-new-cases-in-singapore- } \\
\text { including-certis-cisco-staff-who-had- } \\
\text { served }\end{array}$ \\
\hline Italy & 2-Feb & 1 & 56 & $\begin{array}{l}\text { https://www.aa.com.tr/en/europe/italy- } \\
\text { reports-third-confirmed-case-of- } \\
\text { coronavirus/1726934 }\end{array}$ \\
\hline US & 29-Jan & 0 & 195 & $\begin{array}{c}\text { https://edition.cnn.com/2020/02/10/us/coro } \\
\text { navirus-american-evacuees- } \\
\text { release/index.html }\end{array}$ \\
\hline Total & NA & 14 & 1401 & \\
\hline
\end{tabular}


medRxiv preprint doi: https://doi.org/10.1101/2020.05.02.20088724; this version posted May 8, 2020. The copyright holder for this preprint (which was not certified by peer review) is the author/funder, who has granted medRxiv a license to display the preprint in perpetuity.

All rights reserved. No reuse allowed without permission.

Figure 1 Combined analysis of infection rates of different populations

\section{Contributorship}

H.Q.: literature search, study design, data collection, data analysis, data interpretation, writing Z.J.C:data collection

Z.D.:data interpretation

L.T.:study design, data interpretation

H.H.:study design, data interpretation, writing

Funding: none.

Competing interests: none to declare.

Data sharing statement: no additional data. 
medRxiv preprint doi: https://doi.org/10.1101/2020.05.02.20088724; this version posted May 8, 2020. The copyright holder for this preprint (which was not certified by peer review) is the author/funder, who has granted medRxiv a license to display the preprint in perpetuity.

All rights reserved. No reuse allowed without permission.

\section{Reference:}

1. Wu Z, McGoogan JM. Characteristics of and Important Lessons From the Coronavirus Disease 2019 (COVID-19) Outbreak in China: Summary of a Report of $72 \square 314$ Cases From the Chinese Center for Disease Control and Prevention. JAMA. 2020.

2. Oke J, Heneghan C. Global Covid-19 Case Fatality RatesUPDATED 7th April 2020. Available from: https://www.cebm.net/covid-19/global-covid-19-case-fatality-rates/.

3. Day M. Covid-19: four fifths of cases are asymptomatic, China figures indicate. BMJ. 2020;369:m1375.

4. $\quad \mathrm{Wu}$ JT, Leung K, Leung GM. Nowcasting and forecasting the potential domestic and international spread of the 2019-nCoV outbreak originating in Wuhan, China: a modelling study. Lancet (London, England). 2020;395(10225):689-97. 
Event Lower Upper rate limit limit Z-Value $p$-Value

Japan

$\begin{array}{lllll}0.016 & 0.008 & 0.030 & -12.277 & 0.000\end{array}$

Korea

$\begin{array}{lllll}0.003 & 0.000 & 0.019 & -5.897 & 0.000\end{array}$

Germany

Singapore

$\begin{array}{lllll}0.016 & 0.004 & 0.062 & -5.767 & 0.000\end{array}$

Italy

$\begin{array}{lllll}0.011 & 0.002 & 0.073 & -4.486 & 0.000\end{array}$

$\begin{array}{lllll}0.018 & 0.003 & 0.116 & -3.971 & 0.000\end{array}$

$\begin{array}{lllll}0.003 & 0.000 & 0.039 & -4.215 & 0.000\end{array}$

0.013

0.008

$0.022-16.371$

0.000
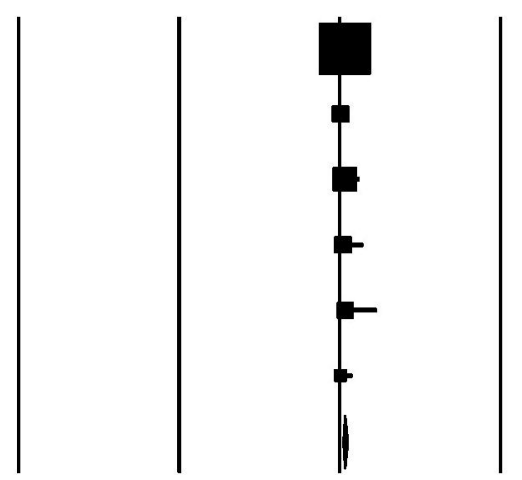

$-1.00 \quad-0.50$

0.00

0.50

1.00

Favours A

Favours B 